\title{
Microwave Drying for Production of Rehydrated Foods: A Case Study of Stink Bean (Parkia speciosa) Seed
}

\author{
Mudtorlep Nisoa ${ }^{1,2}$, Karaket Wattanasit ${ }^{1}$, Arlee Tamman ${ }^{1}$ (D), Yaowarat Sirisathitkul ${ }^{3, *(D)}$ \\ and Chitnarong Sirisathitkul 2 (D)
}

1 Plasmas and Electromagnetic Wave Science Center of Excellence, Walailak University, Nakhon Si Thammarat 80160, Thailand; nmudtorl@wu.ac.th (M.N.); karaket.wat@mail.wu.ac.th (K.W.); arleet@tint.or.th (A.T.)

2 School of Science, Walailak University, Nakhon Si Thammarat 80160, Thailand; schitnar@mail.wu.ac.th

3 School of Engineering and Technology, Walailak University, Nakhon Si Thammarat 80160, Thailand

* Correspondence: syaowara@mail.wu.ac.th; Tel.: +66-75-672-947

Citation: Nisoa, M.; Wattanasit, K.;

Tamman, A.; Sirisathitkul, Y.;

Sirisathitkul, C. Microwave Drying for Production of Rehydrated Foods: A Case Study of Stink Bean (Parkia speciosa) Seed. Appl. Sci. 2021, 11, 2918. https://doi.org/10.3390/ app11072918

Academic Editor: Anabela Raymundo

Received: 27 February 2021

Accepted: 22 March 2021

Published: 24 March 2021

Publisher's Note: MDPI stays neutral with regard to jurisdictional claims in published maps and institutional affiliations.

Copyright: (c) 2021 by the authors. Licensee MDPI, Basel, Switzerland. This article is an open access article distributed under the terms and conditions of the Creative Commons Attribution (CC BY) license (https:/ / creativecommons.org/licenses/by/ $4.0 /)$.
Featured Application: Microwave drying is implemented in the production of rehydrated food, as demonstrated in the case of stink beans.

Abstract: The potential of microwave drying in the production of rehydrated foods is demonstrated with stink beans (Parkia speciosa), smelly legumes of Africa and Asia. Compared to stink beans dehydrated by convective drying and freeze drying, the microwave products exhibit higher moisture contents, but the distribution of microscopic pores leads to good rehydration characteristics. Dehydration by microwave drying is also achieved within a much shorter period than that commonly used in freeze drying. The dehydration time can be further reduced to $6 \mathrm{~h}$ comparable to convective drying, and the moisture content is dropped to $11 \%$ by decreasing the pressure during microwave drying. However, the rehydration time remains around $65 \mathrm{~min}$ for products from both ambient and low-pressure (400 Pa) microwave drying. In rehydration, the period is successfully reduced to $30 \mathrm{~min}$ by increasing the water temperature to $70^{\circ} \mathrm{C}$. The results indicate that microwave drying does not affect the value of crude protein and rehydrated products are comparable to fresh stink beans. From these findings, the microwave drying technique is an applicable technology for both manufacturers and consumers, with acceptable drying time and rehydration characteristics.

Keywords: microwave drying; freeze drying; convective drying; rehydrated food; stink bean

\section{Introduction}

Nowadays, rehydrated foods are very much in consumer demand because of their long shelf life without refrigeration, low contamination, volume decrease as well as ease of consumption and worldwide distribution. Rehydration is a complicated process utilized in food and is directed to bring back its original properties. The dried products are usually immersed in water during their use in food preparation. Rehydration characteristics and the retention of sensory qualities depend on structural changes after drying. Short drying time, high energy efficiency and maintaining the quality after drying are desirable. Product quality, physical appearance and rehydration time for dried products have therefore been improved to fulfill the needs of consumers. Examples of products from rehydration research are lyophilized rice [1] and vegetable and fruit powder beverages [2].

Drying technology can preserve foods by virtue of the evaporation of water and, hence, reducing the moisture content. There are several review drying techniques offered to fruits and vegetables [3] and the food processing industry [4]. Nowadays, drying is a way to add value to modern food products, not only a way to preserve foodstuffs. There are various drying techniques applied to agricultural products such as okara [5], beans [6], honeydew 
honey powders [7], red beetroot [8], and medical plants [9]. Each drying technique has unique advantages, making them candidates in the production of rehydrated foods.

Convective drying produces dehydrated products with an extended shelf life. Heat is transferred from the surface into the food via hot air from a steam coil or fuel oils. With the circulation speed in the range of $0.5-5 \mathrm{~m} / \mathrm{s}$, the hot air will flow through the food usually prepared in the thickness of $2-6 \mathrm{~cm}$ and placed on a tray. If the temperature is higher than $70^{\circ} \mathrm{C}$, the dehydration rate may be too high. This technique is widely used for producing dehydrated vegetables and fruits because of the relatively low price and reasonable maintenance cost. However, the heating is unlikely to be uniform in various positions in the oven because of the uneven air flows. The drying characteristics of the sample are investigated, such as kiwifruits [10] and Mexican serviceberry fruit [11]. In addition to the dehydration, rehydration characteristics of green pea [12], pumpkin [13], and carrot [14] were reported.

Freeze drying is a dehydration process by the sublimation of a frozen product. The operations at low temperatures reduce microbial growth or impede a spoilage reaction to preserve the final product [15]. This method is suitable for foods that are sensitive to heat loss and nutritional value, giving rise to high quality products with good recovery properties. The drying characteristics of cherry [16], stink bean powder [17], stink bean [18] and acorn [19] were investigated. In addition to dehydration, the rehydration of strawberry [20] and mussel [21] were also characterized. Freeze drying is widely used to produce commercial rehydrated foods but has a high cost compared to conventional drying [22,23].

Microwave drying is based on dielectric heating by electromagnetic waves. In addition to a high drying rate within a short time, microwave drying tends to preserve the nutritional values of foods. It is a technology that is suitable for drying raw materials with low humidity. Microwave drying has already been applied to various products, i.e., fish [24], durian [25], instant noodles [26], Gastrodia elata Blume [27], potato cubes [28], amaranth leaves [29], bitter melon [30], and sweet potato chips [31]. The major drawback of microwave drying is its nonuniform heating, particularly the overheating at the sample edges [32]. To overcome these shortcomings, microwave drying has been combined with other drying methods.

Microwave vacuum drying has received much attention because of its high energy efficiency, a significant reduction in the drying time, and a superior quality of dehydrated products [33]. By utilizing microwave waves to rotate the water molecules and generate heat under a low-pressure condition, the obtained food products have high nutritional and sensory qualities, without severe shrinkage [34]. Microwave vacuum drying has already been applied to various products, i.e., blueberries [35], pumpkin [36], herbs [37], potato cubes [38], carrot [39], and apple [40]. The microwave vacuum drying and rehydration characteristics of rice [1], turnip seed [33], green bell pepper [41], squid shreds [42], shiitake mushroom [43], bird nest [44], pumpkin [45], and button mushroom [46] were investigated. Microwave vacuum drying is an innovative technology, but it has not been fully utilized in the commercial production of rehydrated foods.

One of the challenging cases of rehydrated food is stink bean (Parkia speciosa) or bitter bean, a perennial plant in the pea or bean family (Fabaceae) found naturally in Southeast Asia, South Asia and Africa [47]. The beans come in bright green seedpods $30-45 \mathrm{~cm}$ long with $15-20$ beans per pod. Its name comes from its peculiar smell as it has a skunky or gaseous, methane-like aroma. Stink beans are called by local names in different regions, e.g., Yongchak in India, Peteh or Petai in Malaysia and Singapore, and Sataw or Sator in Thailand and Indonesia [17,47-49]. They are classified into two types, namely sataw kow and sataw dahn. The former is rounder, nuttier, and less stinky. Unlike twisted sataw kow, sataw dahn's bean pods are straight, hence the name dahn or gradahn (plank) [50]. Previous studies indicate that sataw is rich in vitamin A, calcium, phosphate, sulfidic acid, polyphenolic compounds, and antioxidant capacity [47,51-58]. It possesses antidiabetic and antihypertensive bioactive peptides [47,59] and active organic compounds including flavonoids, saponins, and tannins $[47,50,53]$. Stink beans exhibit the highest 
concentrations of phytochemicals and biological activity and likely compete in functional food markets [47,49]. Stink bean peels demonstrate a potential to remove azo dye [60].

Stink beans are widely consumed in various Asian cuisines as both raw and cooked foods [47]. At present, the preservations are in forms of pickled stink beans in sour brine normally eaten with chili sauce and fresh frozen stink beans with an even stronger aroma. Most recipes still prefer the fresh stink bean to fresh frozen ones. In the monsoon season, there are abundant stink beans, resulting in a price drop. By contrast, their supplies are insufficient during the off-season and thus not available for consumption throughout the year. Additionally, the major problem for fresh stink beans is that the high water content leads to deterioration, so they become rotten. To prolong their production chain on the market, dehydration is the most common way to preserve stink beans by reducing the water activity and expand product distributions with an extended shelf life. Nowadays, stink beans are developed in forms of powders [17] and freeze-dried products [18], but there is no report about the rehydration of dried stink bean.

This research work firstly compares the dehydration as well as rehydration characteristics of stink beans from microwave drying with those from convective drying and freeze drying. The dehydration time is successfully reduced by lowering the pressure in the microwave drying system previously used to dry fish [24] and durian [25]. Finally, it is demonstrated that the rehydration time is shortened by soaking the dehydrated products in water of increasing temperatures.

\section{Materials and Methods}

\subsection{Dehydration of Stink Bean}

Fresh samples of stink bean were collected in a local market in Thasala district, Nakhon Si Thammarat, Thailand. After their removal from their pods and shells, the stink beans were cut into half-seeds for drying. These stink beans initially contained $73.08 \%$ moisture, comparable to those in previous reports $[17,47,51]$. Three different dehydration methods were carried out in equipment shown in Figure 1 and are detailed as follows.

(1) Convective drying: Approximately $1185 \mathrm{~g}$ of stink beans was placed on the trays and dried in a convective oven at the Food Technology laboratory of Walailak University, Thailand at $60^{\circ} \mathrm{C}$ for $6 \mathrm{~h}$. The drying time was determined based on the characteristics of drying curves in preliminary experiments. To achieve moisture content down to $5 \%$, a drying time shorter than $6 \mathrm{~h}$ would require an increase in temperature, which is the critical cause of the degradation of the nutritional value of plants and seeds [17]. The total phenolic compound reduces significantly if the temperature exceeds $60^{\circ} \mathrm{C}$ [61]. The temperature of $60^{\circ} \mathrm{C}$ was therefore selected to ensure that nutritional quality is retained.

(2) Freeze drying: Stink beans of about $400 \mathrm{~g}$ were dried for $72 \mathrm{~h}$ at about $-70{ }^{\circ} \mathrm{C}$ in a freeze dryer (Christ, gamma 2-16 LSCplus, Osterode am Harz, Germany), operated at the maximum fan speed.

(3) Microwave drying: Stink beans of about $200 \mathrm{~g}$ were dried in a $600 \mathrm{~W}$ microwave drying system, previously designed and constructed for fish and durian drying [24,25], at $35^{\circ} \mathrm{C}$ for $10 \mathrm{~h}$ and at $40^{\circ} \mathrm{C}$ for $6 \mathrm{~h}$. The drying time was determined based on the period needed to reduce the moisture content down to $15 \%$. A microwave vacuum dryer was also developed by reducing the pressure in the microwave cavity with a rotary pump [44]. This low-pressure microwave drying was carried out under the pressure of around $400 \mathrm{~Pa}$ at $35^{\circ} \mathrm{C}$ until reaching a comparable moisture. 


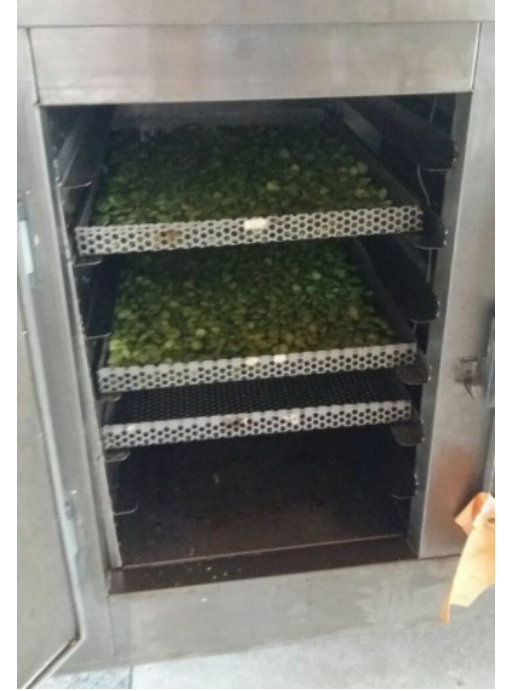

(a)

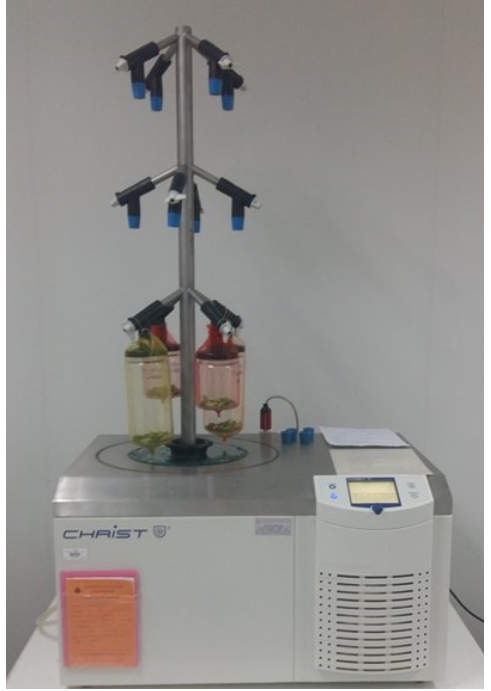

(b)

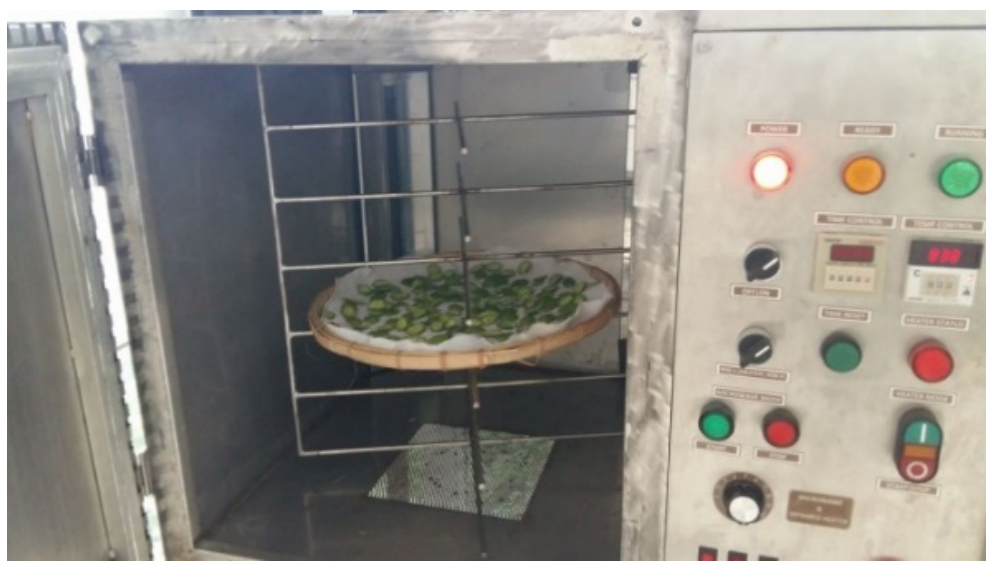

(c)

Figure 1. Equipment for drying stink beans in this research; (a) Convective drying, (b) Freeze drying, and (c) Microwave drying.

\subsection{Characterization of Dehydrated Stink Bean}

The moisture content in dried stink beans was characterized according to method 950.46 of Association of Official Analytical Chemists (AOAC) [62]. The crude protein was determined from the amount of nitrogen content using the Combustion Method (Leco TruSpec CN, protein factor 6.25). The surface morphology of dried stink beans was imaged by a field-emission scanning electron microscope (FESEM: Zeiss Merlin compact, Carl Zeiss Microscopy GmbH, Jena, Germany). With the reduction in water, the specific energy consumptions were estimated from the ratio of total electrical power supplied to the amount of water removed by the microwave and convective drying processes.

\subsection{Rehydration of Dehydrated Stink Bean}

The dried stink beans were immersed in $50 \mathrm{~mL}$ distilled water at a controlled temperature of $38^{\circ} \mathrm{C}$. The rehydration was terminated after the weight of stink beans was constant. As the rehydration time was recorded, the stink beans were removed from the water and characterized. In the case of microwave drying, the comparison of colors of dehydrated and rehydrated products was aided by smartphone colorimetry. The application Colorimeter (Research Lab Tools) was employed on an Android smartphone (Oppo A5 2020), previously calibrated with the HunterLab's MiniScan EZ spectrophotometer in the Batik color measurement [63]. The Commission internationale de l'éclairage (CIE) L* 
(lightness), $a^{*}$ (redness to greenness), and $b^{*}$ (yellowness to blueness) were averaged from three points on each seed. The rehydration time and appearance of stink beans rehydrated at $38{ }^{\circ} \mathrm{C}, 50{ }^{\circ} \mathrm{C}$, and $70{ }^{\circ} \mathrm{C}$ were also compared. The rehydration process in commercial products is typically carried out at temperatures below $80^{\circ} \mathrm{C}$ [64]. The temperature of $38^{\circ} \mathrm{C}$ was selected to test the rehydration near ambient conditions, whereas $50^{\circ} \mathrm{C}$ was selected based on previous reports on the rehydration of food materials [29,64]. The studies on stink beans reveal that the cooking and leaching of material into the rehydration solution occur rapidly at temperatures over $70^{\circ} \mathrm{C}$. The highest temperature used in this work was therefore $70^{\circ} \mathrm{C}$. The rehydration temperature was also comparable to the studies in [46].

\section{Results and Discussion}

\subsection{Characterization and Rehydration of Stink Beans Dehydrated by Different Methods}

The comparison of moisture contents in Table 1 highlights the advantage of freeze drying with negligible water left after $72 \mathrm{~h}$. By using convective drying, the dehydration time can be substantially reduced and the moisture content is lower than $5 \%$ within $6 \mathrm{~h}$. Microwave drying at $35^{\circ} \mathrm{C}$ for $10 \mathrm{~h}$ leaves the moisture over $13 \%$ in the stink beans. Interestingly, an increase in the temperature from 35 to $40^{\circ} \mathrm{C}$ in drying decreases dehydration time, and a moisture content of $12 \%$ is obtained after microwave drying for $6 \mathrm{~h}$. The relatively high moisture in products by microwave drying can be explained based on the classification of water into free, multilayer, and monolayer states. The free water is weakly bound and therefore conveniently evaporated by every method. Prolonged heating removes the water in multilayer and monolayer states. Compared to other methods, microwave drying tends to leave more hydration monolayer at cell walls [27]. However, a lower temperature of microwave drying generally results in high-quality dried products, such as preserving higher phenolic compounds [65].

Table 1. Drying characteristics of dehydrated stink beans from different drying processes.

\begin{tabular}{ccccc}
\hline Drying Methods & $\begin{array}{c}\text { Dehydration Time } \\
\text { (h) }\end{array}$ & $\begin{array}{c}\text { Starting Weight } \\
\text { (g) }\end{array}$ & $\begin{array}{c}\text { Specific Energy Consumption } \\
\text { (MJ/kg) }\end{array}$ & $\begin{array}{c}\text { Moisture Content } \\
\text { w.b. (\%) }\end{array}$ \\
\hline Convective Dryingat $60^{\circ} \mathrm{C}$ & 6 & 1185 & $75 \pm 6$ & $4.23 \pm 0.21$ \\
Freeze Drying at $-70^{\circ} \mathrm{C}$ & 72 & 400 & $\mathrm{~N} / \mathrm{A}$ & 0 \\
Microwave Dryingat $35^{\circ} \mathrm{C}$ & 10 & 200 & $146 \pm 9$ & $13.6 \pm 0.7$ \\
Microwave Dryingat $40^{\circ} \mathrm{C}$ & 6 & 200 & $102 \pm 8$ & $11.6 \pm 0.6$ \\
\hline
\end{tabular}

The specific energy consumptions of microwave and convective drying are shown in Table 1 . The values over $100 \mathrm{MJ} / \mathrm{kg}$ are rather high for microwave drying but comparable to a previous report on shiitake mushroom drying [43]. In contrast to the comparison from carrot drying by Gilandeh et al. [14], the specific energy consumptions by microwave dehydration are higher than those by the convective drying of stink beans in this report. Such a difference is related to the much larger size of this convective oven. The oven is capable of dehydrating more than $1 \mathrm{~kg}$ of stink beans, whereas the loading for the microwave oven is only around $200 \mathrm{~g}$. A combination of microwave with hot air drying was recommended to increase the dehydration efficiency [23]. The initial convective drying followed by microwave heating reduces the drying time, while the quality of dried products is maintained.

Table 2 shows the external appearance of dehydrated stink beans. All products slightly change their shape and colors. The green color becomes distinctly darker in the case of stink beans from microwave drying. Corresponding to the highest moisture content, the product from microwave drying at $35^{\circ} \mathrm{C}$ is closest to the fresh stink beans. Freeze drying results in a very brittle product with the smallest deformation. The deformation after microwave drying is a slightly more than that caused by freeze drying, but significantly lower than convective drying. These findings are consistent with the report from other fruits and vegetables [23]. 
Table 2. External appearance and rehydration time of dried stink bean from different drying processes.

\begin{tabular}{|c|c|c|c|c|}
\hline \multirow{2}{*}{ Drying Methods } & \multirow{2}{*}{$\begin{array}{l}\text { Dehydration Time } \\
\text { (h) }\end{array}$} & \multicolumn{2}{|c|}{ Appearance } & \multirow{2}{*}{$\begin{array}{c}\text { Rehydration Time in } 38^{\circ} \mathrm{C} \\
\text { Water (min) }\end{array}$} \\
\hline & & Dehydrated Product & After Rehydration & \\
\hline $\begin{array}{c}\text { Convective } \\
\text { Dryingat } 60{ }^{\circ} \mathrm{C}\end{array}$ & 6 & & & 90 \\
\hline $\begin{array}{l}\text { Freeze Dryingat } \\
-70{ }^{\circ} \mathrm{C}\end{array}$ & 72 & & & 120 \\
\hline $\begin{array}{c}\text { Microwave } \\
\text { Dryingat } 35^{\circ} \mathrm{C}\end{array}$ & 10 & & & 65 \\
\hline $\begin{array}{c}\text { Microwave } \\
\text { Dryingat } 40{ }^{\circ} \mathrm{C}\end{array}$ & 6 & & & 65 \\
\hline
\end{tabular}

Surface morphologies of dehydrated stink beans are compared by FESEM images. The freeze-dried product tends to lose texture elasticity and exhibits some small pores on the surface in Figure 2b. Freeze drying is known to preserve the structure of dried products. However, greater degradation of aromatic contents due to prolonged drying and the cost of the system must be taken into account for commercial production [66]. Microwave drying results in several large micropores scattered on the surface, as shown in Figure 2c. With similar micropores but a larger distribution, the stink bean after convective drying in Figure 2a has a rougher surface. According to the report of fruits and vegetables drying by microwave [23], the number of pores is reduced but the pores are generally larger than those obtained from the freeze drying and convective drying methods. Such porous structures facilitate the rehydration of dried food [2]. It was reported that drying at elevated temperature led to large pores, increasing the grain rehydration [67].

After immersion in $38^{\circ} \mathrm{C}$ water for different periods of time, photographs of dehydrated stink beans are shown in Table 1 . All dehydrated stink beans were successfully restored to their original half-seed shape. The decision to terminate the rehydration is validated by the softness at the surface and the light green color of fresh stink beans. In addition, the rehydrated products regain the distinct aroma of fresh stink beans. According to the mass spectrometry-based electronic nose profiles by Asikin et al. [48], dominant volatile aroma components including alcohol, aldehyde as well as sulfur compounds in stink beans are varied and likely affect the perception and acceptance of consumers. The rehydration time is varied and can be related to the morphology of dehydrated stink beans. Structure degradation and collapse reduce the water absorption capacity, whereas the 
pores allow more water diffusion. With the smallest pore size, the freeze-dried products need as long as $120 \mathrm{~min}$ to rehydrate. The rehydration time is reduced to $90 \mathrm{~min}$ in the case of convective drying, and stink beans dehydrated by microwave take only $65 \mathrm{~min}$. From this finding, it is fitting to correlate the rehydration time to the moisture content. It can be understood that the freeze dried stink beans require the longest rehydration time, followed by those from convective drying. The remaining moisture in the dried products is generally undesirable but beneficial in reducing rehydration times for these dried stink beans. The results confirm that microwave drying does not cause severe structural change and the food characteristics are preserved in rehydrated products [10].

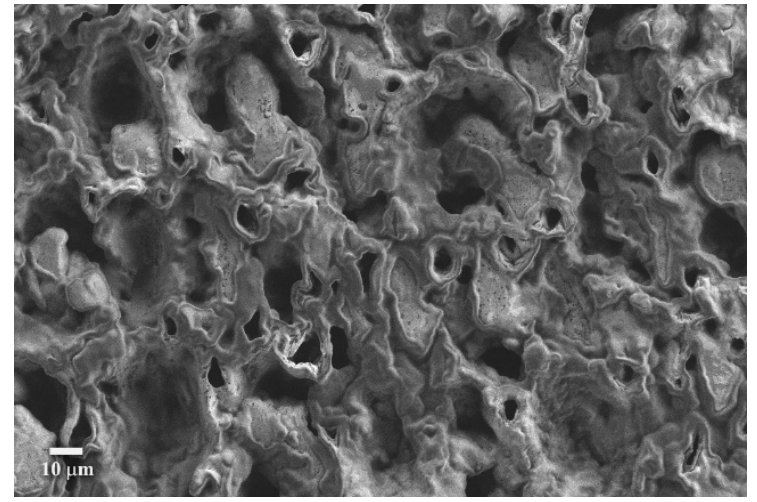

(a)

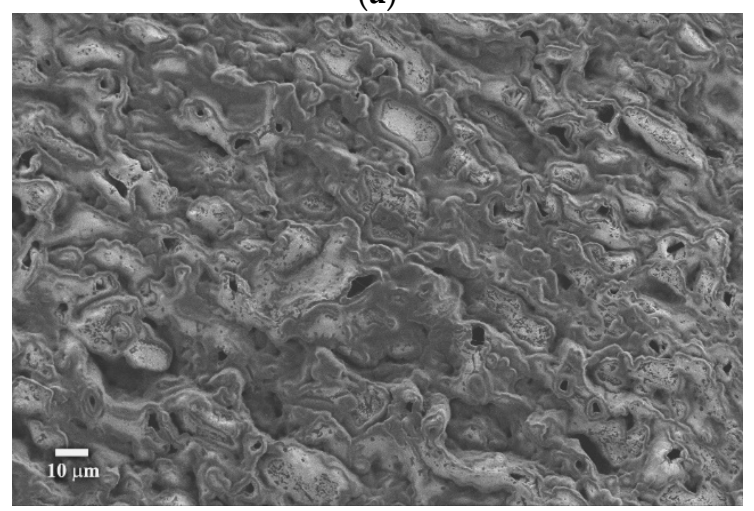

(c)

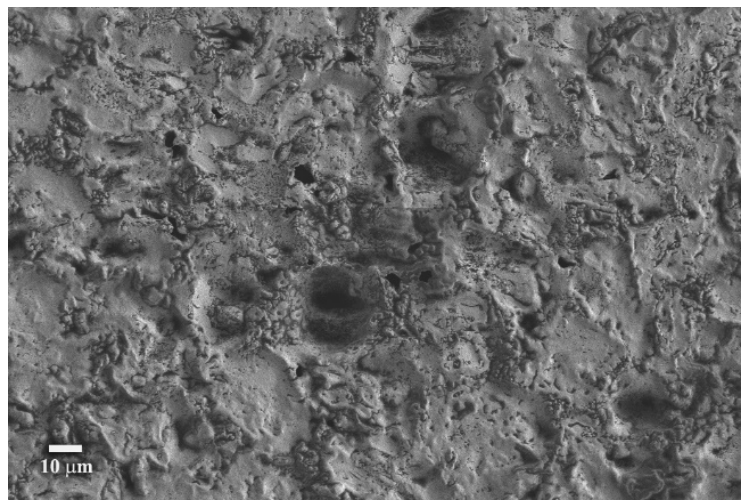

(b)

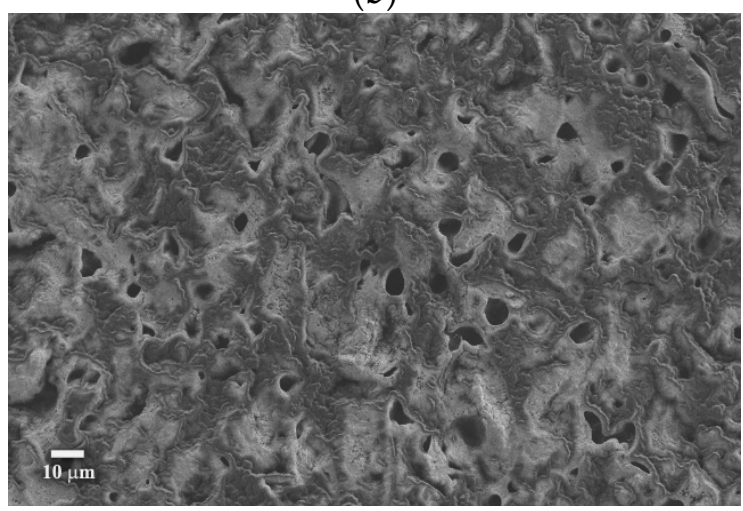

(d)

Figure 2. FESEM images of dried stink beans from (a) Convective drying $\left(60^{\circ} \mathrm{C}\right)$, (b) Freeze drying $\left(-70{ }^{\circ} \mathrm{C}\right)$, (c) Microwave drying $\left(35^{\circ} \mathrm{C}\right)$, and $(\mathbf{d})$ Microwave drying $\left(40{ }^{\circ} \mathrm{C}\right)$.

\subsection{Reduction in Dehydration and Rehydration Times}

As microwave drying is generally appropriate for low-moisture foods, it takes a long time to dehydrate fresh stink beans with the moisture exceeding $70 \%$. In addition to the increase in temperature shown in 3.1, the dehydration time by microwave can be shortened by the reduction in pressure during drying. Vacuum pressure and higher microwave power produce more pores without increasing shrinkage [41]. It follows that the diffusion of water through rehydrated products is increased.

The low pressure of 400 Pa during microwave drying gives rise to dark green products comparable to those dehydrated by microwave at the increased temperature of $40{ }^{\circ} \mathrm{C}$. As compared in Table 3, the reduction in pressure from $101 \mathrm{kPa}$ to $400 \mathrm{~Pa}$ decreases the dehydration time from $10 \mathrm{~h}$ to $6 \mathrm{~h}$. However, the rehydration still needs around $65 \mathrm{~min}$. In both cases, the color of seed coats greatly changes after the rehydration. As compared in Table 4, the CIE $\mathrm{L}^{*}$ value is almost doubled, consistent with the change from dark to lighter in color. The effect of pressure during microwave drying is shown by the CIE $a^{*}$ and $b^{*}$ values. As a result of drying at a lower pressure of $400 \mathrm{~Pa}, a^{*}$ is smaller and $b^{*}$ is larger corresponding to the color closer to that of fresh stink beans. Moreover, the shape 
and size are fully restored, indicating that structural damages by microwave drying are not severe. As shown in Figure 3, stink beans after low-pressure microwave drying have a more uniform surface and smaller pores than those dried at ambient pressure.

Table 3. External appearance and rehydration time of dried stink bean from microwave drying with ambient and low pressures.

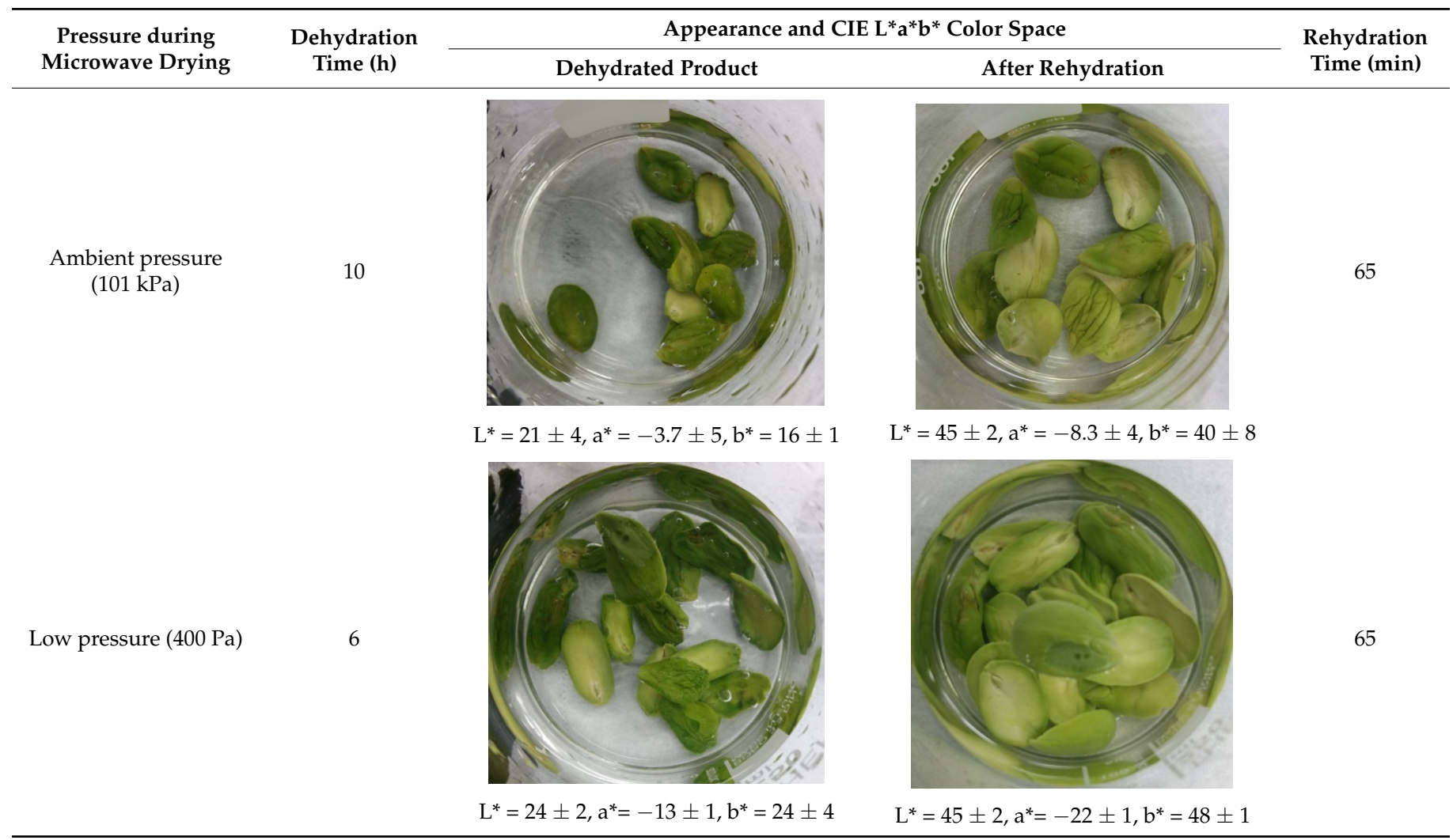

Table 4. Moisture and crude protein in dried stink beans dehydrated by microwave at $35^{\circ} \mathrm{C}$ with two different pressures compared to fresh stink beans.

\begin{tabular}{ccc}
\hline Stink Bean & Moisture Content w.b. (\%) & Crude Protein (\%) \\
\hline Fresh & $73.1 \pm 3.7$ & 31.02 \\
Microwave drying at $101 \mathrm{kPa}$ & $15.7 \pm 0.8$ & 31.23 \\
Microwave drying at $400 \mathrm{~Pa}$ & $11.3 \pm 0.6$ & 30.41 \\
\hline
\end{tabular}

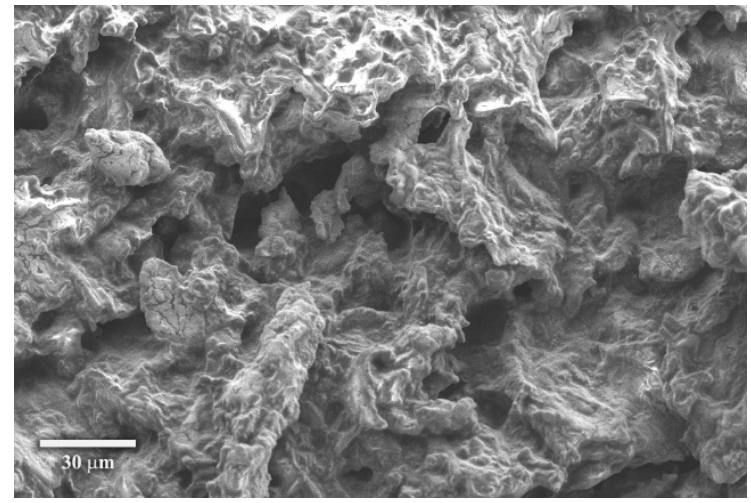

(a)

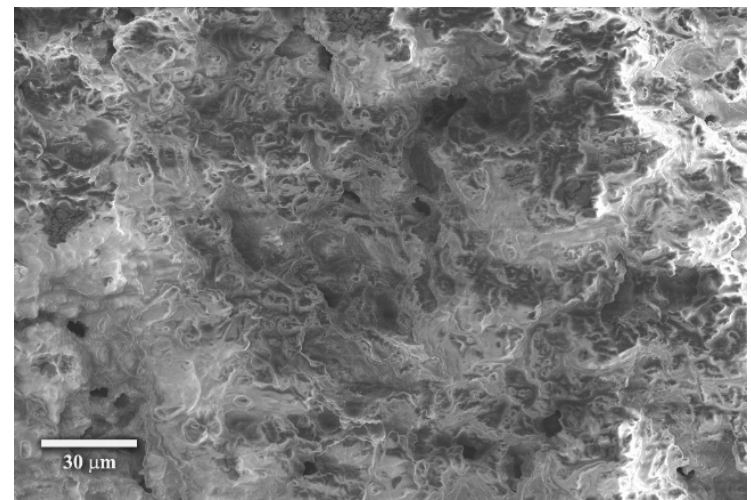

(b)

Figure 3. FESEM images of stink beans dehydrated by microwave at $35^{\circ} \mathrm{C}$ with (a) ambient pressure (101 kPa), and (b) low pressure (400 Pa). 
The moisture content of $11.3 \%$ in Table 4 highlights the effect of low pressure on the microwave drying of stink beans that more water content is removed within a shorter time. The crude protein in stink beans dehydrated by using ambient and low pressures is comparable around $30 \%$. As the combined uncertainty from the sample preparation and protein analysis method can be as high as $1 \%$, these protein values are considered unchanged from those of the fresh stink bean, highlighting that the relatively low temperature in microwave drying could preserve the high protein present in stink beans [47]. In this work, the crude protein of dried stink beans is measured exclusively in the case of microwave drying at $35{ }^{\circ} \mathrm{C}$ because the proteins are likely degraded by drying at higher temperatures $[68,69]$. As demonstrated by Miranda et al. [61], the protein in quinoa seeds was reduced by $10 \%$ after convective drying at $40-80{ }^{\circ} \mathrm{C}$. The report on squid shreds indicated that microwave drying slightly affected the protein content [42].

Finally, the rehydration time is significantly reduced by increasing the water temperature. As shown in Table 5, the products fully restore their original shape and color after immersion in $50{ }^{\circ} \mathrm{C}$ and $70{ }^{\circ} \mathrm{C}$ for, respectively, $40 \mathrm{~min}$ and $30 \mathrm{~min}$. The measurements on seed coats in Table 5 show some similar trends to those in Table 3. The rehydrated products exhibit increases in $\mathrm{L}^{*}$ and $b^{*}$ values. However, the $\mathrm{a}^{*}$ value is only reduced in the case of $50{ }^{\circ} \mathrm{C}$, suggesting that the major change after rehydration is not the greenness but the lightness component. Furthermore, both values are increased with increasing temperature in the rehydration. The reduction in rehydration time is consistent with the suggestion in the literature that a higher temperature increases water absorption as well as the rehydration rate [28]. After a rapid rise in water due to the initial moisture difference, the reductions in viscosity and the surface tension of water at elevated temperature are increasingly influential in the later stage of rehydration [29].

Table 5. External appearance and rehydration time of dried stink bean using different water temperatures.

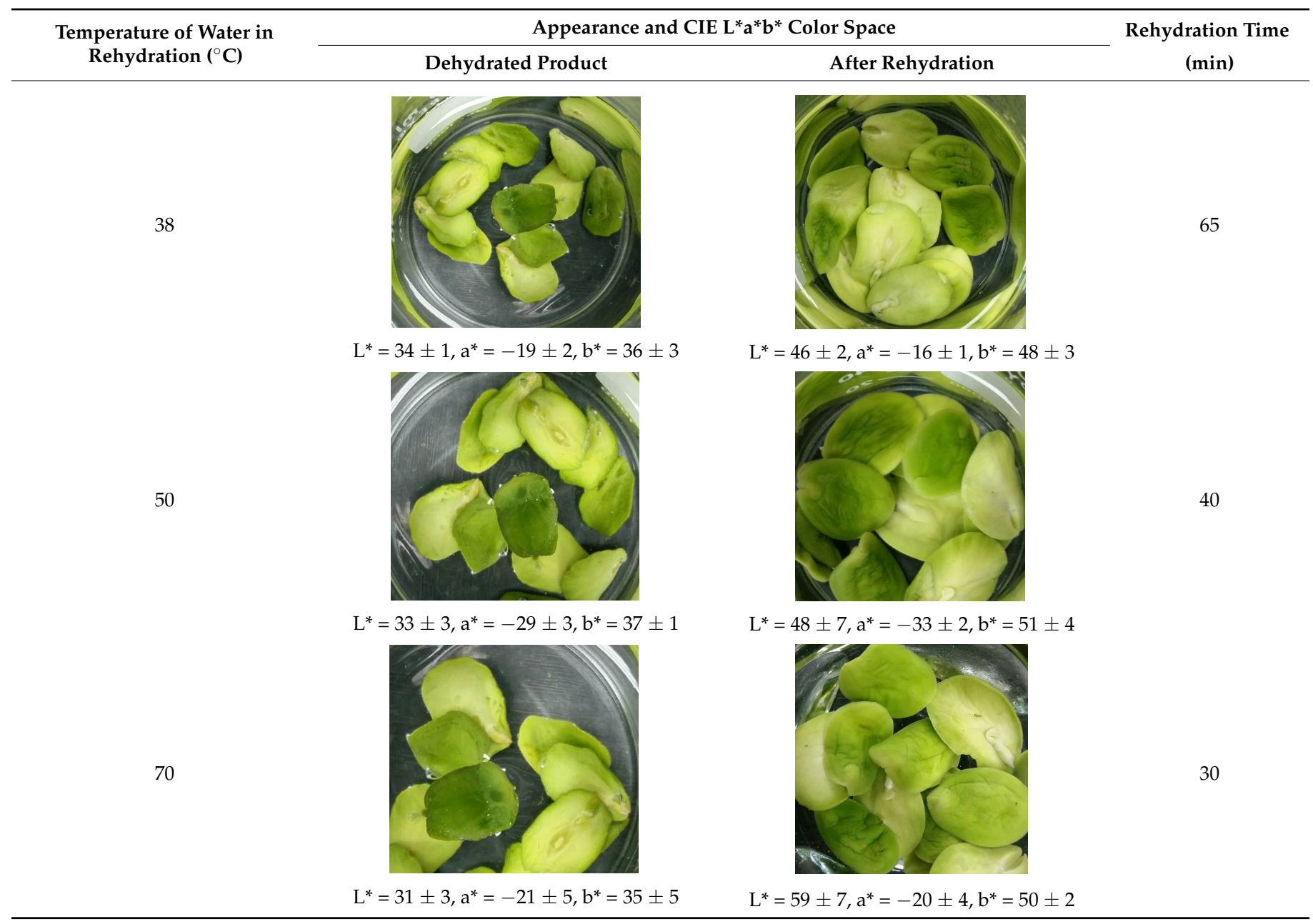




\section{Conclusions}

The stink bean was demonstrated as a rehydrated food produced from microwave drying. Microwave drying at $35^{\circ} \mathrm{C}$ gave rise to a moisture content of $14 \%$, higher than that in convective and freeze-dried products, after $10 \mathrm{~h}$. The dehydration time was successfully decreased to $6 \mathrm{~h}$ by either increasing the temperature to $40^{\circ} \mathrm{C}$ or decreasing the pressure to $400 \mathrm{~Pa}$. This study revealed that stink beans can be dried by using microwaves in a much shorter time compared with freeze drying. With uniform porous characteristics, the dehydrated stink beans can restore their shape, color, and aroma after immersion in water for $65 \mathrm{~min}$. The rehydration time can be reduced to $30 \mathrm{~min}$ by increasing the water temperature to $70{ }^{\circ} \mathrm{C}$. The results from the rehydration suggest that the microwave drying process is potentially useful for producing a variety of rehydrated foods with superior quality.

Author Contributions: M.N. funding acquisition, supervision and formal analysis; K.W. methodology, investigation and project administration; A.T. methodology and investigation; Y.S. investigation, writing-original draft preparation, review and methodology and editing; C.S. investigation and writing - discussion and conclusion. All authors have read and agreed to the published version of the manuscript.

Funding: This research was funded by the Science and Technology Park, Walailak University and financially supported by the new strategic research project (P2P), Walailak University, Thailand.

Institutional Review Board Statement: Not applicable.

Informed Consent Statement: Not applicable.

Data Availability Statement: The data presented in this study are available on request from the corresponding author.

Conflicts of Interest: The authors declare no conflict of interest.

\section{References}

1. Phukasmas, P.; Songsermpong, S. Instant rice process development: Effect of rice cooking methods on the quality of jasmine instant rice dried by industrial microwave oven. J. Microbiol. Biotechnol. Food Sci. 2019, 9, 330-334. [CrossRef]

2. Bochnak-Niedźwiecka, J.; Świeca, M. Quality of new functional powdered beverages enriched with lyophilized fruits-Potentially bioaccessible antioxidant properties, nutritional value, and consumer analysis. Appl. Sci. 2020, 10, 3668. [CrossRef]

3. Sagar, V.R.; Suresh Kumar, P. Recent advances in drying and dehydration of fruits and vegetables: A review. J. Food Sci. Technol. 2010, 47, 15-26. [CrossRef] [PubMed]

4. Menon, A.; Stojceska, V.; Tassou, S.A. A systematic review on the recent advances of the energy efficiency improvements in non-conventional food drying technologies. Trends Food Sci. Technol. 2020, 100, 67-76. [CrossRef]

5. Guimarães, R.M.; Ida, E.I.; Falcão, H.G.; De Rezende, T.A.M.; Silva, J.D.S.; Alves, C.C.F.; Da Silva, M.A.P.; Egea, M.B. Evaluating technological quality of okara flours obtained by different drying processes. LWT Food Sci. Technol. 2020, 123, 109062. [CrossRef]

6. Belmiro, R.H.; Tribst, A.A.L.; Cristianini, M. Impact of high pressure processing in hydration and drying curves of common beans (Phaseolus vulgaris L.). Innov. Food Sci. Emerg. Technol. 2018, 47, 279-285. [CrossRef]

7. Jedlińska, A.; Wiktor, A.; Witrowa-Rajchert, D.; Derewiaka, D.; Wołosiak, R.; Matwijczuk, A.; Niemczynowicz, A.; Samborska, K. Quality assessment of honey powders obtained by high- and low-temperature spray drying. Appl. Sci. 2021, 11, 224. [CrossRef]

8. Kerr, W.L.; Varner, A. Chemical and physical properties of vacuum-dried red beetroot (Beta vulgaris) powders compared to other drying methods. Dry. Technol. 2020, 38, 1165-1174. [CrossRef]

9. Cortés-Rojas, D.; Souza, C.; Oliveira, W. Assessment of stability of a spray dried extract from the medicinal plant Bidens pilosa L. J. King Saud Univ. Eng. Sci. 2016, 28, 141-146. [CrossRef]

10. Maskan, M. Drying, shrinkage and rehydration characteristics of kiwifruits during hot air and microwave drying. J. Food Eng. 2001, 48, 177-182. [CrossRef]

11. Melgar-Almanza, A.; Horacio Guzmán-Maldonado, S.; Núñez-Colín, C.; Herrera-Hernández, M.G.; Medina-Ramos, G. Effect of drying on antioxidant capacity, physicochemical and functional characteristics of Mexican serviceberry fruit. J. Berry Res. 2015, 5, 97-105. [CrossRef]

12. Kaveh, M.; Abbaspour-Gilandeh, Y. Impacts of hybrid (convective-infrared-rotary drum) drying on the quality attributes of green pea. J. Food Process. Eng. 2020, 43, 13424. [CrossRef]

13. Rojas, M.L.; Silveira, I.; Augusto, P.E.D. Ultrasound and ethanol pre-treatments to improve convective drying: Drying, rehydration and carotenoid content of pumpkin. Food Bioprod. Process. 2020, 119, 20-30. [CrossRef] 
14. Abbaspour-Gilandeh, Y.; Kaveh, M.; Aziz, M. Ultrasonic-microwave and infrared assisted convective drying of carrot: Drying kinetic, quality and energy consumption. Appl. Sci. 2020, 10, 6309. [CrossRef]

15. Ratti, C. Hot air and freeze-drying of high-value foods: A review. J. Food Eng. 2001, 49, 311-319. [CrossRef]

16. Sánchez, V.; Baeza, R.; Chirife, J. Comparison of monomeric anthocyanins and colour stability of fresh, concentrate and freezedried encapsulated cherry juice stored at $38^{\circ} \mathrm{C}$. J. Berry Res. 2015, 5, 243-251. [CrossRef]

17. How, Y.-K.; Siow, L.-F. Effects of convection-, vacuum-and freeze-drying on antioxidant, physicochemical properties, functional properties and storage stability of stink bean (Parkia speciosa) powder. J. Food Sci. Technol. 2020, 57, 4637-4648. [CrossRef] [PubMed]

18. Akbar, M.A.; Karyadi, J.N.W.; Imaniar, D.I.; Mar'Fuah, S.; Hati, F.I.P. Changes of Petai during drying using freeze drying method. IOP Conf. Ser. Earth Environ. Sci. 2019, 355, 012053. [CrossRef]

19. Ahmadi, S.; Sheikh-Zeinoddin, M.; Soleimanian-Zad, S.; Alihosseini, F.; Yadav, H. Effects of different drying methods on the physicochemical properties and antioxidant activities of isolated acorn polysaccharides. LWT Food Sci. Technol. 2019, 100, 1-9. [CrossRef]

20. Huang, L.-L.; Zhang, M.; Yan, W.-Q.; Mujumdar, A.S.; Sun, D.-F. Effect of coating on post-drying of freeze-dried strawberry pieces. J. Food Eng. 2009, 92, 107-111. [CrossRef]

21. Tribuzi, G.; Laurindo, J.B. Dehydration and rehydration of cooked mussels. Int. J. Food Eng. 2016, 12, 173-180. [CrossRef]

22. Monteiro, R.L.; Carciofi, B.A.M.; Marsaioli, A.; Laurindo, J.B. How to make a microwave vacuum dryer with turntable. J. Food Eng. 2015, 166, 276-284. [CrossRef]

23. Figiel, A.; Michalska, A. Overall quality of fruits and vegetables products affected by the drying processes with the assistance of vacuum-microwaves. Int. J. Mol. Sci. 2017, 18, 71. [CrossRef] [PubMed]

24. Pianroj, Y.; Kerdthongmee, P.; Nisoa, M.; Kerdthongmee, P.; Galakarn, J. Development of a microwave system for highly-efficient drying of fish. Walailak J. Sci. Tech. 2006, 3, 237-250.

25. Suwanchote, C.; Weerakul, J.; Sirisathitkul, C.; Nisoa, M. Color and hardness of durian chips irradiated by controlled low power microwave. Food Sci. Biotechnol. 2012, 21, 1767-1770. [CrossRef]

26. Pongpichaiudom, A.; Songsermpong, S. Characterization of frying, microwave-drying, infrared-drying, and hot-air drying on protein-enriched, instant noodle microstructure, and qualities. J. Food Process. Preserv. 2017, 42, e13560. [CrossRef]

27. Subramaniam, S.; Wen, X.-Y.; Jing, P. One-step microwave curing-dehydration of Gastrodia elata Blume: Relationship between phytochemicals, water states and morphometric characteristics. Ind. Crop. Prod. 2020, 153, 112579. [CrossRef]

28. Hizaji, A.S.; Maghsoudlou, Y.; Jafari, S.M. Effect of water temperature, variety and shelf life of rehydration kinetics of mi-crowave dried potato cubes. Lat. Am. Appl. Res. 2011, 41, 249-254.

29. Mujaffar, S.; Loy, A.L. The rehydration behavior of microwave-dried amaranth (Amaranthus dubius) leaves. Food Sci. Nutr. 2017, 5, 399-406. [CrossRef]

30. Nguyen, T.; Nguyen, Q.; Nguyen, P.; Tran, B.; Huynh, P.T. Effects of drying conditions in low-temperature microwave-assisted drying on bioactive compounds and antioxidant activity of dehydrated bitter melon (Momordica charantia L.). Food Sci. Nutr. 2020, 8, 3826-3834. [CrossRef]

31. Monteiro, R.L.; De Moraes, J.O.; Domingos, J.D.; Carciofi, B.A.M.; Laurindo, J.B. Evolution of the physicochemical properties of oil-free sweet potato chips during microwave vacuum drying. Innov. Food Sci. Emerg. Technol. 2020, 63, 102317. [CrossRef]

32. Nijhuis, H.; Torringa, H.; Muresan, S.; Yuksel, D.; Leguijt, C.; Kloek, W. Approaches to improving the quality of dried fruit and vegetables. Trends Food Sci. Technol. 1998, 9, 13-20. [CrossRef]

33. Reyes, A.; Campos, C.; Vega, R. Drying of turnip seeds with microwaves in fixed and pulsed fluidized beds. Dry. Technol. 2006, 24, 1469-1480. [CrossRef]

34. Barreto, I.; Tribuzi, G.; Junior, A.M.; Carciofi, B.; Laurindo, J. Oil-free potato chips produced by microwave multiflash drying. J. Food Eng. 2019, 261, 133-139. [CrossRef]

35. Zielinska, M.; Michalska, A. Microwave-assisted drying of blueberry (Vaccinium corymbosum L.) fruits: Drying kinetics, polyphenols, anthocyanins, antioxidant capacity, colour and texture. Food Chem. 2016, 212, 671-680. [CrossRef] [PubMed]

36. Nawirska, A.; Figiel, A.; Kucharska, A.Z.; Sokół-Łętowska, A.; Biesiada, A. Drying kinetics and quality parameters of pumpkin slices dehydrated using different methods. J. Food Eng. 2009, 94, 14-20. [CrossRef]

37. Calín-Sánchez, Á.; Figiel, A.; Lech, K.; Szumny, A.; Martínez-Tomé, J.; Carbonell-Barrachina, Á.A. Dying methods affect the aroma of Origanum majorana L. analyzed by GC-MS and descriptive sensory analysis. Ind. Crop. Prod. 2015, 74, 218-227. [CrossRef]

38. Bondaruk, J.; Markowski, M.; Błaszczak, W. Effect of drying conditions on the quality of vacuum-microwave dried potato cubes. J. Food Eng. 2007, 81, 306-312. [CrossRef]

39. Nahimana, H.; Zhang, M. Shrinkage and color change during microwave vacuum drying of carrot. Dry. Technol. 2011, 29, 836-847. [CrossRef]

40. Ando, Y.; Hagiwara, S.; Nabetani, H.; Sotome, I.; Okunishi, T.; Okadome, H.; Orikasa, T.; Tagawa, A. Effects of prefreezing on the drying characteristics, structural formation and mechanical properties of microwave-vacuum dried apple. J. Food Eng. 2019, 244, 170-177. [CrossRef]

41. Kumar, V.; Devi, M.K.; Panda, B.K.; Shrivastava, S.L. Shrinkage and rehydration characteristics of vacuum assisted microwave dried green bell pepper. J. Food Process. Eng. 2019, 42, 13030. [CrossRef] 
42. Pankyamma, V.; Mokam, S.Y.; Debbarma, J.; Rao, M.B. Effects of microwave vacuum drying and conventional drying methods on the physicochemical and microstructural properties of squid shreds. J. Sci. Food Agric. 2019, 99, 5778-5783. [CrossRef] [PubMed]

43. Kantrong, H.; Tansakul, A.; Mittal, G.S. Drying characteristics and quality of shiitake mushroom undergoing microwave-vacuum drying and microwave-vacuum combined with infrared drying. J. Food Sci. Technol. 2014, 51, 3594-3608. [CrossRef] [PubMed]

44. Nisoa, M.; Kerdtongmee, P. Low-pressure microwave heating system for drying of swiftlet bird's nest. In Proceedings of the 3rd International Conference on Agricultural and Food Engineering, Kuala Lumpur, Malaysia, 23-25 August 2016.

45. Monteiro, R.L.; Link, J.V.; Tribuzi, G.; Carciofi, B.A.; Laurindo, J.B. Microwave vacuum drying and multi-flash drying of pumpkin slices. J. Food Eng. 2018, 232, 1-10. [CrossRef]

46. Pei, F.; Shi, Y.; Mariga, A.M.; Yang, W.-J.; Tang, X.-Z.; Zhao, L.-Y.; An, X.-X.; Hu, Q.-H. Comparison of freeze-drying and freeze-drying combined with microwave vacuum drying methods on drying kinetics and rehydration characteristics of button mushroom (Agaricus bisporus) slices. Food Bioprocess. Technol. 2014, 7, 1629-1639. [CrossRef]

47. Chhikara, N.; Devi, H.R.; Jaglan, S.; Sharma, P.; Gupta, P.; Panghal, A. Bioactive compounds, food applications and health benefits of Parkia speciosa (stinky beans): A review. Agric. Food Secur. 2018, 7, 46. [CrossRef]

48. Asikin, Y.; Kusumiyati; Shikanai, T.; Wada, K. Volatile aroma components and MS-based electronic nose profiles of dogfruit (Pithecellobium jiringa) and stink bean (Parkia speciosa). J. Adv. Res. 2018, 9, 79-85. [CrossRef]

49. Ghasemzadeh, A.; Jaafar, H.Z.E.; Bukhori, M.F.M.; Rahmat, M.H.; Rahmat, A. Assessment and comparison of phytochemical constituents and biological activities of bitter bean (Parkia speciosa Hassk.) collected from different locations in Malaysia. Chem. Cent. J. 2018, 12, 12. [CrossRef]

50. Wonghirundecha, S.; Benjakul, S.; Sumpavapol, P. Total phenolic content, antioxidant and antimicrobial activities of stink bean (Parkia speciosa Hassk.) pod extracts. Songklanakarin J. Sci. Technol. 2014, 36, 301-308.

51. Jongjareonrak, A.; Saelim, K.; Benjakul, S. Changes of antioxidant activities of stink beans (Parkia speciosa Haask) during storage. Agric. Sci. J. 2008, 39, 95-98. (In Thai)

52. Jongjareonrak, A.; Saelim, K.; Benjakul, S. Effect of $\mathrm{pH}$ and heating on antioxidant activities of stink beans. Agric. Sci. J. 2010, 41, 87-90. (In Thai)

53. Hasim; Faridah, D.; Kurniawati, D.A. Antibacterial activity of Parkia speciosa Hassk peel to Escherichia coli and Staphylo-coccus aureus bacteria. J. Chem. Pharm. 2015, 7, 239-243.

54. Wong, S.P.; Leong, L.P.; Koh, J.H.W. Antioxidant activities of aqueous extracts of selected plants. Food Chem. 2006, 99, 775-783. [CrossRef]

55. Kamisah, Y.; Othman, F.; Qodriyah, H.M.S.; Jaarin, K. Parkia speciosa Hassk: A potential phytomedicine. Evid. Based Complement. Altern. Med. 2013, 2013, 709028. [CrossRef]

56. Tocmo, R.; Liang, D.; Wang, C.; Poh, J.; Huang, D. Organosulfide profile and hydrogen sulfide-releasing capacity of stinky bean (Parkia speciosa) oil: Effects of pH and extraction methods. Food Chem. 2016, 190, 1123-1129. [CrossRef]

57. Gan, C.-Y.; Latiff, A.A. Antioxidant Parkia speciosa pod powder as potential functional flour in food application: Physicochemical properties' characterization. Food Hydrocoll. 2011, 25, 1174-1180. [CrossRef]

58. Ravichandran, V.; Vasanthi, S.; Shalini, S.; Shah, S.A.A.; Tripathy, M.; Paliwal, N. Green synthesis, characterization, antibacterial, antioxidant and photocatalytic activity of Parkia speciosa leaves extract mediated silver nanoparticles. Results Phys. 2019, 15, 102565. [CrossRef]

59. Siow, H.-L.; Gan, C.-Y. Extraction of antioxidative and antihypertensive bioactive peptides from Parkia speciosa seeds. Food Chem. 2013, 141, 3435-3442. [CrossRef]

60. Anuar, F.I.; Hadibarata, T.; Muryanto, M.; Yuniarto, A.; Priyandoko, D.; Sari, A.A. Innovative chemically modified biosorbent for removal of procion red. Int. J. Technol. 2019, 10, 776. [CrossRef]

61. Miranda, M.; Vega-Gálvez, A.; López, J.; Parada, G.; Sanders, M.; Aranda, M.; Uribe, E.; Di Scala, K. Impact of air-drying temperature on nutritional properties, total phenolic content and antioxidant capacity of quinoa seeds (Chenopodium quinoa Willd.). Ind. Crop. Prod. 2010, 32, 258-263. [CrossRef]

62. AOAC. Official Methods of Analysis, 17th ed.; The Association of Official Analytical Chemists: Washington, DC, USA, 2000.

63. Sirisathitkul, Y.; Kaewareelap, S. Color analysis of batik fabric by facile smartphone colorimetry. Int. J. Adv. Sci. Eng. Inf. Technol. 2021, 11, 84-91. [CrossRef]

64. Zurabravo, L.; Ahhen, K.; Vegagalvez, A.; Garciasegovia, P.; LemusMondaca, R. Effect of rehydration temperature on functional properties, antioxidant capacity and structural characteristics of apple (Granny Smith) slices in relation to mass transfer kinetics. J. Food Process. Eng. 2013, 36, 559-571. [CrossRef]

65. Ferenczi, S.; Czukor, B.; Cserhalmi, Z. Evaluation of microwave vacuum drying combined with hot-air drying and compared with freeze- and hot-air drying by the quality of the dried apple product. Period. Polytech. Chem. Eng. 2014, 58, 111-116. [CrossRef]

66. Calín-Sánchez, Á.; Lipan, L.; Cano-Lamadrid, M.; Kharaghani, A.; Masztalerz, K.; Carbonell-Barrachina, Á.A.; Figiel, A. Comparison of traditional and novel drying techniques and its effect on quality of fruits, vegetables and aromatic herbs. Foods 2020, 9, 1261. [CrossRef] [PubMed]

67. Prasert, W.; Suwannaporn, P. Optimization of instant jasmine rice process and its physicochemical properties. J. Food Eng. 2009, 95, 54-61. [CrossRef] 
68. Matsuura, Y.; Takehira, M.; Joti, Y.; Ogasahara, K.; Tanaka, T.; Ono, N.; Kunishima, N.; Yutani, K. Thermodynamics of protein denaturation at temperatures over $100^{\circ} \mathrm{C}$ : CutA1 mutant proteins substituted with hydrophobic and charged residues. Sci. Rep. 2015, 5, 15545. [CrossRef] [PubMed]

69. Kishore, D.; Kundu, S.; Kayastha, A.M. Thermal, chemical and ph induced denaturation of a multimeric $\beta$-galactosidase reveals multiple unfolding pathways. PLoS ONE 2012, 7, e50380. [CrossRef] [PubMed] 